\title{
Of Fish and Fishermen: Shifting Societal Baselines to Reduce Environmental Harm in Fisheries
}

Mimi E. Lam $^{1,2}$

\begin{abstract}
If reasonable fishery harvests and environmental harms are specified in new regulations, policies, and laws governing the exploitation of fish for food and livelihoods, then societal baselines can shift to achieve sustainable fisheries and marine conservation. Fisheries regulations can limit the environmental and social costs or harms caused by fishing by requiring the fishing industry to pay for the privilege to fish, via access fees for the opportunity to catch fish and extraction fees for fish caught; both fees can be combined with a progressive environmental tax to discourage overcapitalization and overfishing. Fisheries policies can be sustainable if predicated on an instrumental and ethical harm principle to reduce fishing harm. To protect the public trust in fisheries, environmental laws can identify the unsustainable depletion of fishery resources as ecological damage and a public nuisance to bind private fishing enterprises to a harm principle. Collaborative governance can foster sustainable fisheries if decision-making rights and responsibilities of marine stewardship are shared among government, the fishing industry, and civil society. As global food security and human welfare are threatened by accelerating human population growth and environmental impacts, decisions of how to use and protect the environment will involve collective choices in which all citizens have a stake - and a right.
\end{abstract}

Key Words: collaborative fisheries governance; common heritage of mankind principle; conservation; disincentives to overcapitalize and overfish; ecological damage; environmental ethics; environmental protection; fishing harm; harm principle; law of nuisance; marine stewardship; precautionary principle; public trust doctrine; sustainable fisheries

\section{INTRODUCTION: OF FISH AND FISHERMEN}

The best-laid schemes $o^{\prime}$ mice an' men

Gang aft agley,

An' lea'e us nought but grief an' pain,

For promis'd joy!

(Robert Burns 1785)

The best developed plans and schemes

will remain unimplemented

if they do not take into account

political realities.

(Lawrence Juda 1999:98)

The Ecology and Society Special Feature, The Privilege to Fish (Lam and Calcari Campbell 2012), articulates the nuances of fishing rights and duties. Fisheries problems stalemate when individual or cultural values clash over the allocation and management of dwindling fishery resources. Solutions can come from shifting cognitive and societal baselines of what is acceptable for shared resources. I argue that shifting societal baselines of acceptable behavior can reduce environmental harm in fisheries. Enabled by environmental laws and fisheries regulations that reduce fishing harm, individual attitudes and behaviors can shift to foster shared decision-making rights and responsibilities of marine stewardship. Only with such shifts will ecology and society be able to sustain living fish, their habitats, and fishing communities, for present and future generations of fish and humans.
The opening quote inspired the title for Of Mice and Men by John Steinbeck (1937). The novel is about a simple-minded man, Lennie, who loves to pet soft things, such as rabbits, but his fondness for rabbits inevitably harms them, as he does not know his own strength. This is an apt allegory for humanity's relationship with fish. We love consuming and catching fish so much that we are destroying the populations upon which we depend for food, livelihood, recreation, and culture. To develop fisheries management plans and policies that do not irrevocably harm fish populations, we need to re-examine our relationship with fish, lest we be left with the null solution: the fisheries problems are solved because there are no fish left. Lennie, with his blind physical strength, is a metaphor for industrial-scale fisheries, which possess immense fishing capacity through sophisticated but often non-selective technology (Pitcher and Lam 2010), leaving fish prey to intense human predation. In contrast, small-scale fisheries catch about the same amount of fish for human consumption (Pauly 2006), employing more fishermen with more selective fishing technology, but causing less environmental harm.

Figure 1 evokes a range of complex interactions in the exploitation of fishery resources, from local small-scale to global large-scale fisheries, reflecting the growing tension between fishing for food and fishing for profit (Lam and Pitcher 2012a). With increasing technology, commoditization of fishery products, and global trade, enabled often by government subsidies favoring industrial fishing fleets, local fishermen and fishing communities are being supplanted by

${ }^{1}$ University of British Columbia, Fisheries Centre, Policy and Ecosystem Restoration in Fisheries, ${ }^{2}$ University of New Mexico, Department of Biology 
Fig. 1. From Local Fishermen to Global Fishing Vessels

a) Lone fisherman with rod fishing among oyster farms in Pearl River Estuary near Macau, China. Most of South China Sea has been depleted of small fish by large-scale bottom trawling (Cheung and Pitcher 2008). Photo credit: Mimi E. Lam (2008). b) A traditional artisanal seine net fishery has existed for generations on Lake Malawi, Africa, targeting an herbivorous tilapia, chambo (Oreochromis spp.), which is unique to the lake and forms the national dish of Malawi. The fish are sold daily at many beaches around the lake. Beginning in the 1970s, foreign development aid projects supplied nylon nets and outboard engines for the boats, greatly increasing fishing power, which ultimately contributed to the collapse of the Malawian chambo fishery (Turner 1995). Photo credit: Tony J. Pitcher (1987). c) Fishermen cleaning their nets on "slereks," traditional wooden purse seiners, in the Bali Strait sardine fishery in the village of Pengambengan, Indonesia. Female gleaners in the water run fishmeal businesses, just one of many unofficial livelihoods in the community supported by this local unreported fishery (Buchary et al. 2011). Photo credit: Tony J. Pitcher (2003). d) Heavily-subsidized, million-Euro, deep-sea bottom trawlers in the small village of Kinsale Harbor, West Cork, Ireland. Owner-operators are organized in a fishermen's cooperative with considerable local political power. Such vessels have been implicated in circumventing European Union (EU) regulations (Pramod and Pitcher 2006). Photo credit: Tony J. Pitcher (2006). e) Salmon drum purse seiner with crew operating in Johnstone Strait, British Columbia. Most of the commercial fleet, including this vessel, is corporately owned by Canfisco, the largest salmon canner in Canada. Federal regulations have favored this sector over other, mostly owner-operated sectors (Power-Antweiler and Pitcher 2008). Photo credit: Neil Winkelmann (2008). f) Atlantic Dawn, an Irish-owned, highlysubsidized, factory freezer trawler, was banned by the EU, but continued to operate in West Africa and elsewhere with laxer regulations (Heinberg 2003). Now renamed the Annelies Ilena, registered in the Netherlands, and repainted, the world's largest fishing vessel has been seen fishing off the coast of British Columbia, Canada. Photo credit: Bjørn Ottosen (Port of Bergen, Norway, 2000).

a.

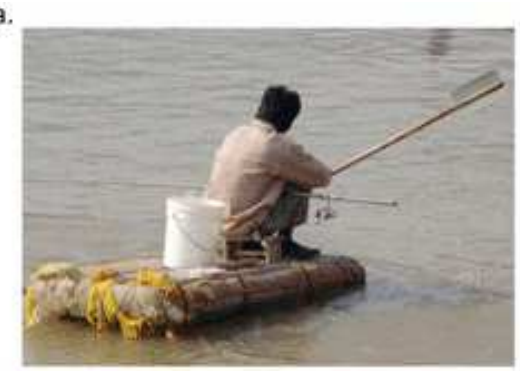

c.
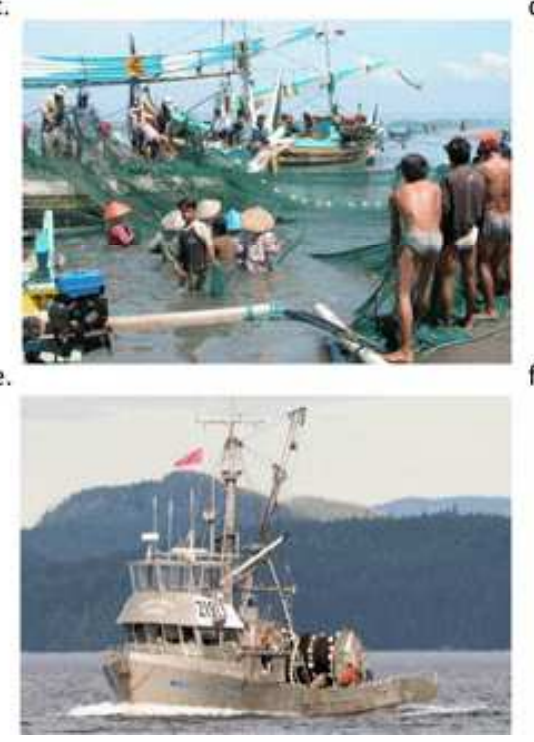

b.

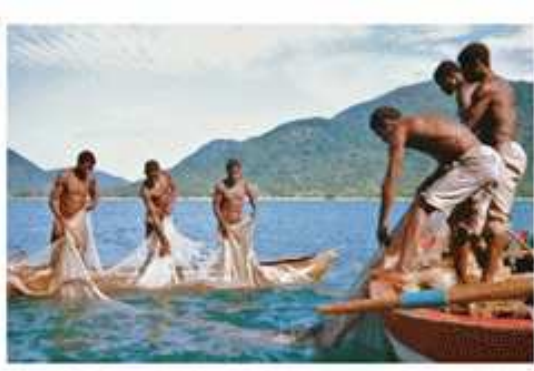

d.

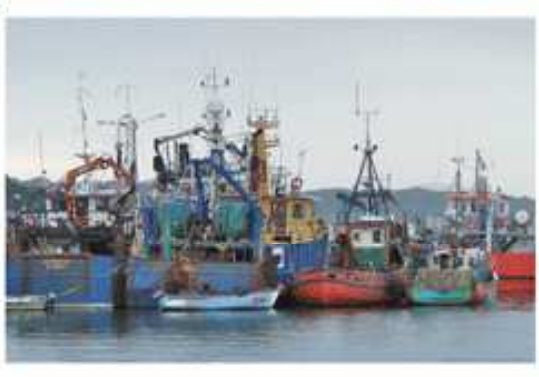

f.

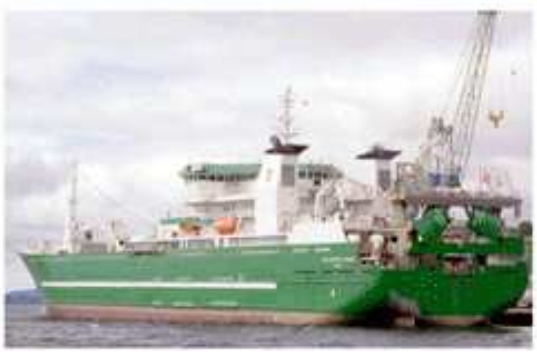


highly-mechanized global fishing vessels. With rationalization in fisheries policy promoting economic efficiency (Bromley 1990, 2009), fishing boats have become bigger, fishermen fewer, and fish smaller and fewer. Declining trends in size and abundance of fish were dramatically highlighted by an analysis of coral reef fish caught by recreational fishermen in the Florida Keys (McClenachan 2009a,b). But economic efficiency may not breed ecological or social efficiency: fishermen employing sophisticated technology can now track fish unprotected by international law in the deep and high seas, while transnational, cross-sector, corporate fishing enterprises are outcompeting many fishing communities for food and livelihoods. Humans have even culled marine mammals to protect the economic interests of the fishing industry (Pauly and Maclean 2003), despite limited direct competition for prey (Trites et al. 1997).

In English Common Law countries, the public has a right to fish (Bader 1998, Harris 2009), but it is limited. The Food and Agriculture Organization (FAO) of the United Nations (UN) specifies: "The right to fish carries with it the obligation to do so in a responsible manner so as to ensure effective conservation and management of the living aquatic resources" (FAO 1995:4). In Canada, Aboriginal rights to fish (see, e.g., Jones et al. 2010) for food, social, and ceremonial purposes are constitutionally protected and after conservation, take priority over commercial and recreational harvests, but federal actions that prevent harm may infringe this right (Harris 2008). In the developing world, most fisheries have been historically open access, with fishing characterized as a mostly unmanaged human right to food security (Pitcher and Lam 2010). In developed countries, complex webs of legal conditional rights to fish now exist, given and retracted piecemeal by governments in power (Eagle and Kuker 2010). Modern centralized government authority has typically overridden traditional community rights, where rights to fish were assigned as privileges granted or stripped by the community, with governance mechanisms including strong incentives, sanctions, and reciprocity to foster a local stewardship ethic and effective fisheries management (Trosper 2002, 2003, Johnsen 2009). Today, fisheries sustainability pivots on reconciling the human rights for food and livelihood (Allison et al. 2012) with the impacts of fishing on biomass conservation, biodiversity, and ecosystem services, which can cause irrevocable damage to ecosystems and ultimately, harm to society.

To take into account political realities (see quote from Juda 1999), I argue for incorporating a precautionary principle that is both instrumental and ethical, a harm principle in fisheries. Drawing on legal notions of harm as a social or environmental cost, I will propose mechanisms for its reduction. Fishing harm can be reduced via a tiered approach: (1) regulate the fishing industry with management tools that internalize the social and environmental costs of fishing, by requiring fishermen to pay for the privilege to fish via access and extraction fees, both scaled with fishing capacity; (2) develop fisheries policies with the explicit goal to reduce fishing harm so as to help achieve sustainable fisheries and marine conservation; (3) legislate binding laws to create and regulate societal norms that protect the public trust in fisheries; and (4) adopt a collaborative fisheries governance framework that shares the decisionmaking rights and responsibilities of marine stewardship among government, the fishing industry, and civil society.

\section{SHIFTING SOCIETAL BASELINES: YIELDING THE 'RIGHT TO FISH'}

...

They that have wrought the end unthought

Be neither saint nor sage,

But only men who did the work

For which they drew the wage.

Wherefore to these the Fates shall bend

(And all old idle things)

Wherefore on these shall Power attend

Beyond the grip of kings:

Each in his place, by right, not grace

Shall rule his heritage -

The men who simply do the work

For which they draw the wage.

(Rudyard Kipling 1902)

Shifting societal baselines reflect the dynamic tension between private rights and public values. The 'right to fish', as the 'right to pollute', fails to consider external costs. Baselines of what constitutes inalienable rights and reasonable costs of doing business have shifted across history, as 'externalities' have become 'internalized' (Lam and Pauly 2010). Cost internalization requires that the social costs of an activity (the externalities) be charged to that activity (internalized), so that the private costs reflect the costs imposed on society (Pigou 1932). Externalized environmental costs caused by activities of resource appropriators should also be imposed on those activities (Bergkamp 2001). Human activity often results in negative externalities or 'harms' to others (Lin 2006). Fishing is no exception. To limit social and environmental costs or harms, the governance of contractual relations would have to be redefined (Williamson 1979). To reduce harm caused by fishing, governance mechanisms must manifest the 'privilege to fish'.

Historically, patterns of resource appropriation have shifted, as resource availability diminished with human population growth (Lam and Pauly 2010). Emerging social institutions and legislation govern resource use by redefining individual and state rights and duties. They reflect shifting societal sensibilities regarding liabilities of property and damage related to natural resources, human laborers, and the environment. In the workplace, where slaves were once the 
norm, firms now must exercise due care to guarantee the basic welfare of laborers (Lam and Pauly 2010). Whereas polluters were once compensated for preventing air pollution, seen as a provision of a social benefit, they now must bear the cost of pollution causing environmental damage, as reflected in the "polluter pays principle" (Fischel 1995, cited in Lin 2006). These shifting societal baselines are reminiscent of shifting ecological baselines (Pauly 1995), where ecological reference states used by individuals to assess the status of fisheries shift across generations, as fish stocks and individual fish sizes decline with greater exploitation over time. Here, it is cultural norms that shift, reflected in emerging social institutions and legislation that constrain individual attitudes and behaviors.

Social and environmental costs or harms can be internalized with either command-and-control regulations or liability rules, or more typically, both. Applying cost internalization is difficult, however, as it must be determined first, what constitutes a cost, and then of what is it a cost (Bergkamp 2001). With natural resource damage, pertinent legal entitlements or rights must be assigned before the injurer and victim can be identified in conflicting environmental uses. Internalizing an environmental cost also requires deciding on whom the costs are to be imposed or distributed, which may be the polluting firm, parties contracting its services, or consumers who benefit from the reduced costs of services (Bergkamp 2001). As an alternative to regulations and economic incentives in environmental protection, liability regimes can restrict actions that cause harm, such as pollution, and even oblige clean up or restoration of the damaged environment (Pootschi 1996). Harms caused by fishing can similarly be limited.

\section{ENVIRONMENTAL HARMS, LAWS, AND VALUES IN SOCIETY}

Harm, a normative concept, reflects underlying social judgments about what is good and bad. "Until society grapples with the question of what interests matter and how to account for differing values, struggles will continue over environmental law at the boundaries of the harm principle" (Lin 2006:983). The harm principle (Epstein 1995) is reflected in social contract theory, whereby governments are organized principally to prevent citizens from harming each other. It often disguises inevitable societal choices about values (Lin 2006). Consequently, the boundaries of legal rules that grant discretion to use property as desired or to protect against harm regularly shift to reflect changing economic, technological, and cultural factors (Sax 1993, Byrne 2005). Legal harms are "infringements (or threatened infringements) of rights or adverse effects (or significant chance of adverse effects) on protected interests" (Bergkamp 2001:332). Environmental harms are thus setbacks to human interests deemed significant by community norms, such as "immediate and future physical injury, emotional distress from fear of future injury, social and economic disruption, remediation costs, property damage, ecological damage, and regulatory harms" (Lin 2006:928 emphasis added). Harms are prevented or corrected by environmental regulations and laws, such as common law nuisance and toxic tort (Lin 2006): a nuisance is a harmful effect, while a tort is a legal wrong that causes harm.

Environmental laws reduce societal harm by internalizing costs and correcting market failures, while capturing societal values (Bergkamp 2001). "[A]1l decisions in environmental law involve some trade-off between costs and benefits in terms of resource allocation and social welfare" (Ruhl 2000:536). Legal institutions make owners account for the costs or externalities that they might impose on others (Byrne 2005). Advances in environmental legislation include: 1) restrict pollution and protect environmental resources; and 2) integrate and coordinate public environmental laws and regulations (Bergkamp 2001). Public laws affect implementation of public policy or collective interests (Shane 1991), such as the U.S. Clean Air and Water Acts. The natural environment could be granted legal rights within the existing framework of U.S. law, by satisfying three criteria: 1. uphold legal standing for nature by guardianship; 2. recognize harm to the environment itself, and 3. award damages to repair the environment itself (Stone 1972). On Earth Day 2011, Bolivia passed the world's first legislation (Ley de Derechos de la Madre Tierra) to enshrine seven rights for Mother Earth, constituent ecosystems, and human systems (see, e.g., Buxton 2011): the rights to life (and integrity of ecosystems and natural processes), biodiversity, water, clean air, equilibrium, restoration of ecosystems damaged by human activity, and freedom from pollution. Environmental values are captured also in the Earth Charter (2000), a civil society initiative to promote transition to sustainable ways of living and a global society founded on a shared ethical framework. Global society is thus asserting its collective right to protect the environment and share responsibility to determine what is desirable for future, and acceptable for present generations.

Environmental benefits, such as ecosystem services, are public goods (Kahneman and Knetsch 1992). Ruhl (2008) has proposed an ecosystem services nuisance theory of liability, where a diminishment of an ecosystem service, often a positive externality, can constitute a private or public nuisance if it hinders use and enjoyment of land by those who have property rights and privileges. From the American Restatement (Second) of Torts $\S 821 \mathrm{D}$ and $\S 821 \mathrm{~B}$ (1979), a private nuisance is "a nontrespassory interference with a neighbor's possessory interest in the use and enjoyment of land," while a public nuisance is "a nontrespassory interference with a right held by the general public in the use of public facilities or with the public health, safety, or convenience" (Lin 2006:903). That is, landowners hold their property subject to the greater public good and so should not use their property in destructive, negative externality-causing behavior, but rather, should steer it in the direction of stewardship, raising the issue of moral 
nuisances (Nagle 2001). But under American property law, no precedent exists "for the proposition that landowners have rights in the continued flow of ecosystem services from other person's lands" (Ruhl 2007:533). The law of nuisance thus raises ethical issues of distributive justice.

Environmental damage constitutes environmental harms, including "property damage, personal injury, and economic damage" (Bergkamp 2001:9). Damage is thus defined as loss or harm resulting from injury to one's person, property, or reputation, but omits ecological damage. Pardy (2005:39) has proposed ecological damage be defined as a "permanent change caused by human impact to an ecosystem, unless a larger ecosystem can be identified in which no such permanent change is found." Compensation or damages may be awarded for environmental harms, but the reciprocal nature of problems with social costs, such as actions of business firms having harmful effects, requires laws of nuisance and damage be interpreted to avoid the more serious harm to society (Coase 1960). The Coase Theorem (1960), which assumes no transaction costs and perfect information, predicts that an economically efficient outcome in resource allocation does not require government regulation (Lin 2006). However, to account for costs of market transactions, the appropriate social arrangement for dealing with harmful effects must be chosen (Coase 1960), through legal delimitation of rights and government regulation that internalizes social and environmental costs. Aligning private and public interests can achieve socially desirable outcomes with minimal transaction costs in fisheries policy (Wilson 2007). Legislation that restricts private activities to protect the environment from pollutants (Farber 2003, see also Lam and Pauly 2010: Figure 1) include: the U.S. Clean Air $(1963,1970)$ and Water (1972) Acts and their major amendments, the International Convention for the Prevention of Pollution From Ships (MARPOL 73/78), and the international Montreal Protocol on Substances that Deplete the Ozone Layer (1987).

Roman Empire public trust principles have influenced the environmental laws of the English, Spanish, French, and Dutch, and their respective colonies (Sax 1970, Lazarus 1986). In the U.S., the Public Trust Doctrine (PTD) provides that "public trust lands, waters, and living resources are held by a state in trust for benefit of its people, and that they may use these resources for navigation, fishing, commerce, and (in more recent years) recreation" (Fletcher 2006:188). The PTD declares that "a) certain natural resources ... are defined as part of an 'inalienable public trust'; b) certain authorities are designated as 'public trustees' to guard those resources; and c) every citizen, as a beneficiary of the trust, may invoke its terms to hold the trustees accountable and to obtain judicial protection against encroachments or deterioration" (Sand 2007:521). Public trust affirms the duty of the state to protect people's common heritage and obliges state governments to manage ocean resources in the best interests of their citizens
(Turnipseed et al. 2009a,b). Invoked to "protect the health and safety of its citizens and the integrity of its natural resources," the PTD is evolving "from a use doctrine to one that includes resource protection" (Fletcher 2006:200-201). Thus, the common law doctrine of the 'public right to fish' (Bader 1998, Harris 2008) is shifting to a 'public right to protect'.

A shift in the common law's baseline from an anti-ecosystem instrumentalism is being triggered by emerging knowledge about the value of natural capital and ecosystem services (Ruhl 2007). Case laws involving the public trust doctrine, i.e., the duty of the state to protect public resources, and the law of nuisance, i.e., the duty of owners not to harm others, reflect this shift (Ruhl 2007, Ruhl and Salzman 2006). Public trust principles subordinate private land to the public welfare, as property held by individuals in trust for the benefit of society, and justifies state actions geared to protect the environment, as protection of natural resources and ecosystems promotes the general welfare (Wilgus 2001). Similarly, property law is shifting from a frontier to a stewardship ethic, infusing an environmental ethic premised on a broadened concept of nuisance. Relationships among property owners and between property owners and the state are governed by nuisance law, which, enforced by a harm-based test (Ruhl 2007), restricts private property rights by requiring social responsibility in the exercise of ownership (Bader 1998). Nuisance law is thus balancing private rights with public welfare to reflect emerging public awareness of the need for environmental protection (Wilgus 2001).

\section{ETHICAL EVOLUTION IN INTERNATIONAL LAW AND OCEAN MANAGEMENT}

Global organizations also can establish legal and moral standards that fishing nations must meet. Legally binding international agreements for responsible fisheries management are founded on the Third United Nations Convention on the Law of the Sea (UNCLOS III), signed in 1982 and ratified or acceded to in 1994 by 163 states and the European Union(EU). It recognizes sovereignty in the territorial sea, limited by the international servitude of innocent passage, and sovereign rights over the waters to 200 nautical miles beyond the territorial sea, known as the exclusive economic zone (EEZ), declared unilaterally by many countries since the late 1970 s (Juda 1999). UNCLOS III established an international legal framework for the oceans, extending national jurisdiction and specifying coastal states' rights and duties for management and use of fishery resources within their EEZs, representing approximately 90 percent of the world's marine fisheries (FAO 1995; see, e.g., http://www.seaaroundus.org).

Part XI of UNCLOS III declares the seabed and ocean floor and subsoil thereof, beyond the limits of national jurisdiction, and its resources to be the "common heritage of mankind" (CHM), managed by the International Seabed Authority, with all rights belonging to mankind as a whole (Taylor 2011). The 
CHM principle is an ethical concept in international law, establishing legal protection through a trustee relationship for some localities and their resources as the common property of humanity, such that their resources are available for the use and benefit of all citizens, and so cannot be claimed, appropriated, or owned by any state or private entity (Taylor 2011). Despite its adoption in UNCLOS III, the CHM principle has been applied only to a few areas and does not replace the freedom of the high seas; thus, provisions created for the administration and management of the international commons have had little impact. If applied, the CHM principle could potentially curb current trends towards privatization or enclosure of the ocean commons (Hannesson 2004). It resonates with the public trust concept in U.S. environmental law for natural resource management by states. Proposals to extend the PTD to a federal (Turnipseed et al. 2009a,b) and global public trusteeship for the oceans (Sand 2007, Blumm and Guthrie 2012) would require nations to use and manage ocean resources within their national jurisdiction for the benefit of national and global citizens, respectively.

Non-binding statements of cooperation similarly codify an international morality evolving under customary international law, the global rules and norms of acceptable behavior or practice (Macdonald 1995). For example, the Organisation for Economic Cooperation and Development's polluter pays principle states "the polluter should bear the cost of measures to reduce pollution decided upon by public authorities to ensure that the environment is in an acceptable state" (COM 1993). The precautionary principle, ratified by the 1992 Rio Declaration and the 1995 UN Agreement on Straddling Fish Stocks and Highly Migratory Fish Stocks, "ensures that a substance or activity posing a threat to the environment is prevented from adversely affecting the environment, even if there is no conclusive scientific proof linking that particular substance or activity to environmental damage" (Cameron and Abouchar 1991, cited in Macdonald 1995:256, emphasis added in citation). It reflects a profound shift in environmental ethics (Macdonald 1995) to protect the marine environment (Lauck et al. 1998) and its wild living resources (Mangel et al. 1996). The FAO Code of Conduct for Responsible Fisheries (CCRF), unanimously adopted and ratified by FAO Member States on 31 October 1995, "sets out principles and international standards of behaviour for responsible practices" to ensure "effective conservation, management and development of living aquatic resources, with due respect for the ecosystem and biodiversity" (FAO 1995:1); however, it is non-mandatory.

Failure to comply with non-binding international agreements is not uncommon. Compliance with the CCRF is poor (Pitcher et al. 2008, 2009a,b), with few countries even defining an achievable management goal to track their progress. Both the CCRF and the International Plan of Action to combat illegal, unreported, and unregulated fishing (FAO 2001) are voluntary legal instruments. They specify moral guidelines and measures, but fail to restrict the rights of, nor to impose obligations on member states, and so do not effectively bind states to cooperate in the governance of fishery resources. The social and environmental harms resulting from such noncompliance jeopardize basic human rights to food security and fishermen's livelihoods (Hauck 2008, Pitcher and Lam 2010, Allison et al. 2012). Similarly, fishing access agreements, negotiated and paid by industrialized nations, access coastal waters of developing nations, notably in West Africa, damaging local marine environments and depleting valuable fishery resources of local communities, violating treaty obligations (e.g., Kaczynski and Fluharty 2002). It is clearly in the interests of all fishing nations to minimize irreversible harm to global fisheries, as evident in World Trade Organization negotiations to eliminate harmful fishing subsidies (Sumaila and Pauly 2007, Camping 2009), but these, too, are riddled with conflicting state interests (WTO 2011), such that, in practice, the common good gets compromised, despite the good intentions of legal principles and moral standards.

\section{A HARM PRINCIPLE IN FISHERIES}

The goal of preventing harm to others has been the most politically compelling rationale for government intervention in regulating public health risks (Pope 2000): in regulating the environmental risks of fishing, the goal of avoiding harm to society could similarly be made a central tenet of fisheries policies. While this may be politically challenging in some jurisdictions, an unequivocal approach to sustain fisheries would be to develop fisheries policies with the explicit goal of preventing harm to human interests mediated by the environment, i.e., instrumental or libertarian harm, as well as harm to the environment itself, i.e., ethical or deontological harm (Lin 2006). Requiring the fishing industry to show that impacts of fishing activities are negligible on ecosystems and thus innocent of ecological damage would implement the precautionary principle and reverse the burden of proof advocated in fisheries management (Garcia 1994, Macdonald 1995, Dayton 1998). This can only succeed, however, if environmental protection is articulated as a clear policy goal (Pedersen 1994), backstopped by environmental laws based on ethical principles of harm, precaution, public trust, and the common heritage of mankind.

As natural resources managed in public trust, living fish now need protection from excessive and destructive private depletion (Lam and Pitcher 2012a). I propose that fishing activities that cause unreasonable depletion of fishery resources and diminishment of ecosystem services should qualify as ecological damage and a public nuisance, to which fishing enterprises are liable. By treating environmental degradation caused by fisheries as a public nuisance, i.e., "an unreasonable interference with a right common to the general public" (Ruhl 2008:775), courts could instill a conservationist 
ethic in fisheries within existing property regimes, by redefining the rights and responsibilities of private fishing enterprises. Environmental damage would need to be defined beyond just damage to property, person, or the environment by pollution, but to encompass depletion of natural resources when public resources become scarce, such as in fisheries. A legal path to sustainable fisheries management would be paved by recognizing 1) that rights and responsibilities associated with property include private possession, use, enjoyment, and disposition that do not harm the public interest, and 2) that environmental damage constitutes a "cognizable harm capable of redress under the law of nuisance" (Wilgus 2001:103). The public right to fish can only be protected if the sustainability of the living resources themselves is not harmed.

Whether or not exploitation of fishery resources is harmful could be assessed with the aid of ecological science to clarify baselines of ecological harm that constitute unreasonable use of property in a nuisance context (Wilgus 2001). The Universal Declaration of Human Rights (1948) guarantees, inter alia, the right to life, liberty, and security of person, including food security. Foresight and political will, supported by relevant science, are needed to create governance mechanisms and societal baselines to mitigate the environmental harms caused by overfishing, with new environmental legislation, regulations, taxes, and fees. Social justice demands that not only incentive mechanisms in fisheries management, but also co-governance relations in the environmental laws of property, damage, and nuisance be re-examined. To determine legal responsibilities in the public and private sectors regarding natural resources, corresponding internal costs, liability, and negligence must be specified (Bergkamp 2001). With a universal policy goal to reduce environmental harm and effective institutional linkages, mechanisms, and instruments, regulations that limit fishing harms could be then implemented.

Under the common law doctrine of naturae ferae and law of capture, private property rights are assigned to fishermen who capture public living resources from their natural state by their skill and effort (Bader 1998, Macinko and Bromley 2004). Constitutional law (legal, written, formalized rules) and common law (evolving, unwritten, informal rules) specify fishing rights and responsibilities (Bader 1998). Both govern individual behaviors within society to frame fisheries management, but the common laws of harm, nuisance, and property are increasingly redefining fisheries policy. To counteract adverse trends in fisheries, laws that reflect shared environmental values for society are shifting societal baselines or norms of acceptable fishing behavior. When a social contract becomes harmful to society, as argued in fisheries (Lam and Pauly 2010), its terms need to be adapted, via new regulatory procedures and incentive mechanisms (Rosenberg 2009), and enabled by restraining legislative acts.

\section{PAYING FOR THE PRIVILEGE TO FISH}

Fisheries scientists and environmental lawyers both grapple with notions of "reasonableness": the former, to set reasonable harvest limits (Pearse and Walters 1992), and the latter, to define reasonable harm (Lin 2006). By specifying reasonable harvests as those that do not inflict unreasonable environmental harm, as assessed by ecological science, fisheries regulation and environmental law can work synergistically to limit private exploitation of public resources. Environmental regulation seeks to correct market failures and ensure that an adequate supply of public goods, such as clean air and water, is available to the public: it regulates risk of harm rather than actual harm (Lin 2006). Risk-based or preventative regulation is premised on collective harms and operates to prevent harm before it occurs (Lin 2006). An economically rational actor is likely to disregard public harms unless their costs are internalized, e.g., through environmental regulation (Spence 2001). Environmental regulations are implemented via prior approvals, permits that embody standards to be met, and monitoring of compliance, all with the goal of preventing harm (Schroeder 2002).

The power of governments in environmental regulation to prohibit or compel and to take or give money selectively benefits or harms all industries within society, as well as individuals within those industries (Stigler 1971). Eminent domain (U.S.) or its equivalent, expropriation (Canada and South Africa), compulsory purchase (United Kingdom, New Zealand, Ireland), and resumption/compulsory acquisition (Australia), all refer to an action by the state to seize a citizen's private property, with due monetary compensation, but without the owner's consent: it is typically exercised by governments to take property for public or civic use, such as public utilities, highways, railroads, and public safety. Countering this in the U.S. is the Takings Clause, which states that private property shall not be taken for public use, without just compensation. Regulatory takings claims are challenging "the proper relationship between the individual and the state" (Epstein 1985, cited in Eagle 2007:621) to determine "who should bear the burdens for society of certain public goods" (Raymond 1996:578). The conflicting roles of government, as both regulator and trustee of public fishery resources, and also facilitator of private fishing enterprises, constrain socially optimal solutions (Eagle 2007, Eagle and Kuker 2010), as regulators are often "captured" by industry (Stigler 1971, Peltzman 1976, 1993).

Various input and output controls regulate fishing (Sissenwine and Mace 2003, Stefansson and Rosenberg 2005) to manage risks, imperfect information, conflicting interests, and natural variability (Pearse and Walters 1992). Input controls restrict access, such as through licenses, gear and vessel restrictions, area closures, and fishing days. Output controls limit harvests, set by the total allowable catch (TAC), combined with catch quotas, which are portions of the TAC allocated by sector, 
gear type, or vessel or to fishermen, communities, or fishery associations. Individual transferrable quotas (Copes 1986, Grafton 1996, Arnason 1998) are widely touted to promote stewardship by giving fishermen effective property rights to fishery resources (Christy 1997, Hannesson 2004, Grafton et al. 2006, Wyman 2008). But quota management schemes are not necessarily instrumental (Costello et al. 2008, Chu 2008, Sumaila 2010) and are patently unethical, as private enterprises are given free access rights to public resources (Macinko and Bromley 2002, Bromley 2008, 2009, Lam and Pauly 2010). To enhance conservation, fisheries management is shifting from 'rights-based fishing' (Neher et al. 1989, Hilborn et al. 2005) to dedicated access privileges (Hilborn 2007, Allison et al. 2012, Lam and Calcari Campbell 2012), which secure access to a portion of the allowable catch, fishing effort, or fishing grounds.

By requiring fishing enterprises to pay for the privilege to fish, some of the social and environmental costs of fishing can be internalized. This can be done through access or entry fees to pay for the opportunity to catch fish and extraction or landing fees to pay for the fish caught. These fees, with other tools, can serve as explicit disincentives to overcapitalize and overfish. An entry fee with a progressive environmental tax scaled with fishing capacity or extractive power, e.g., vessel engine power or gear type, could act as a disincentive to overcapitalize. This would preferentially tax the excessive capacity of large fishing vessels to exploit fishery resources, making vessels with greater potential to damage the environment economically inefficient. This would help 'level the fishing grounds' between commercial and artisanal fishermen. Historically, fisheries management has restricted fishing capacity with input controls, which inadvertently promoted inventiveness to circumvent regulations, but has not imposed costs to restrict fishing technology, which may promote fishing mastery with less damaging technology.

This disincentive to overcapitalize could be combined with a disincentive to overfish. A landing fee or royalty on the value per kilogram of fish landed has been proposed in a "pay-asyou-fish" policy, with the royalty rate established in auctions for limited-term permits for assigned catch shares of the annual TAC (Macinko and Bromley 2002, Bromley 2005, 2008, 2009). As with the entry fee, if the royalty rate on the landed value were scaled with fishing capacity or 'latent fishing effort', e.g., $1 \%$ royalty for smaller vessels and $3 \%$ royalty for larger vessels, then the policy mechanism would discourage excessive fishing capacity and extraction. With these joint regulations, fishermen employing more fishing capacity to catch the same amount of fish and those catching more fish with the same fishing capacity would pay more. The proposed environmental tax and royalty on the entry and landing fees scale with the potential and actual environmental harms caused by fishing activities, which, over time, would begin to reflect their true social and environmental costs. If such disincentives to overcapitalize and overfish were implemented, then fisheries regulations would drive fisheries towards greater ecological efficiency (catching more fish with less ecological damage) and social efficiency (employing more fishermen with socioeconomic incentives aligned with societal goals), rather than greater economic efficiency, with its concomitant depletion of fishery resources. That is, these regulations would reduce the social and environmental costs or harms caused by fisheries.

\section{CONCLUSION}

The opportunity to catch fish, whether for food, livelihood, recreation, or culture, is granted by the state on behalf of its citizens. But now, the technological skill and effort associated with fishing is beyond that needed to deplete stocks (Watson et al. 2012), necessitating restrictions on fishing rights. If society does not change how it regulates fisheries, then when all the fish are gone, humanity loses a valuable source of protein desperately needed to feed a burgeoning population. Living fish also have nonmarket value benefiting humans, such as their ecological and cultural value (Lam and Borch 2011, Lam and Pitcher 2012a). Environmental laws are being rewritten to restrain the destructive fishing power unleashed by technological progress and growing appetite for increasingly scarce fish, kept affordable to consumers by government subsidies to private fishing enterprises. Societal baselines of acceptable harm must shift to restore ecosystems damaged from fisheries impacts, if ecosystems are to be sustained for current and future generations of fish, fishermen, and society.

Societal and ecological baselines can shift, if predicated on an instrumental and ethical harm principle in fisheries management, policies, law, and governance:

1. Regulate the fishing industry with management tools that internalize the social and environmental costs or harms of fishing, by requiring fishermen to pay for the privilege to fish through entry and landing fees, scaled with fishing capacity to reduce overcapitalization and overfishing:

a. access fees that pay for the opportunity to catch fish (law of nuisance); and

b. extraction fees that compensate public owners for fish caught (law of damage).

2. Develop fisheries policies to help achieve sustainable fisheries and marine conservation with the explicit goal to reduce fishing harm:

a. eliminate harmful fishing subsidies to reduce economic incentives for fishing industries to overfish and overcapitalize;

b. condition global fishing access agreements to responsible codes of conduct that build domestic capacity, equitably distribute profits, and sustainably exploit resources; and 
c. create marine protected areas and networks to protect fish and critical habitats.

3. Legislate binding laws to establish societal norms that protect the public trust in fisheries:

a. treat the unsustainable depletion of fishery resources and diminishment of ecosystem services as environmental damage and a public nuisance (e.g., harmful and illegal fishing);

b. ban all environmentally destructive fishing gear and practices, such as dynamite, cyanide, bottom-trawling, and discarding (already banned in the EU), as with the international moratorium for large-scale pelagic driftnet fishing; and

c. enforce sanctions on violators of international treaties and agreements.

4. Adopt a collaborative fisheries governance framework that shares decision-making rights and responsibilities of marine stewardship among government, industry, and civil society:

a. increase accountability and fiduciary responsibilities of government agents;

b. incorporate fishermen's knowledge in co-management and corporate social responsibility within the fishing industry; and

c. involve scientists, environmental lawyers, nongovernmental organizations, and other communities of interest as social stewards to educate public stakeholders, increase consumer awareness, and shift societal baselines of acceptable fishing harm.

Society would be wise to instill a human ethic for aquatic resources or "sea ethic" (Safina 1997, 2003), comparable to Leopold's conservation land ethic (1941): "a thing is right when it tends to preserve the integrity, stability, and beauty of the biotic community." Yielding the right to fish and exercising human grace by reducing our technological might to conserve fish would do that. With new environmental laws and regulations that encapsulate emerging societal values to protect the environment, the incentive structure in fisheries can restrict harmful fishing activities. By requiring fishermen to pay for the privilege to fish, fisheries management can shift from managing fish to managing people (Hilborn 2007), regulating individual behaviors with appropriate incentives, and granting rights of access with societal obligations to not cause undue environmental harm. Collaborative governance mechanisms can etch responsible and ethical fishing behavior
(Lam and Pitcher 2012b) with environmental legislation that goes beyond regulations and market incentives to reduce fishing harm, by limiting resource extraction and promoting social equity. Redefining a dynamic social contract for ethical fisheries by shifting societal baselines to reduce environmental harm and protect humanity's common resources is a collective choice in which all citizens have a stake, and indeed, a right.

Responses to this article can be read online at: http://www.ecologyandsociety.org/issues/responses. $\mathrm{php} / 5113$

\section{Acknowledgments:}

I thank the Gordon and Betty Moore Foundation for sponsoring The Privilege to Fish Special Feature and American Association for the Advancement of Science symposium on which it was based. For this manuscript, I owe a debt of gratitude to various individuals: T. J. Pitcher for contributing his many insights and photos; D. W. Bromley for the lively discussion over a marathon coffee session; J. Eagle, M. Turnipseed, and Global Ecological Integrity Group members for clarifying legal arguments; B. Ottosen and N. Winkelmann for donating their wonderful images; and M. E. Calcari Campbell and L. Gunderson for their editorial advice.

\section{LITERATURE CITED}

Agreement Relating to the Implementation of Part XI of the United Nations Convention on the Law of the Sea of 10 December 1982 (done 28 July 1994, entered into force 28 July 1996), 1836 United Nations Treaty Series 41.

Allison, E. H., B. D. Ratner, B. Åsgård, R. Willmann, R. Pomeroy, and J. Kurien. 2012. Rights-based fisheries governance: from fishing rights to human rights. Fish and Fisheries 13(1): 14-29. http://dx.doi.org/10.1111/ j.1467-2979.2011.00405.X

Arnason, R. 1998. Ecological fisheries management using individual transferable share quotas. Ecological Applications 8(1): S151-S159. http://dx.doi.org/10.2307/2641373

Bader, H. 1998. Who has the legal right to fish? Constitutional and common law in Alaska fisheries management. Marine Advisory Bulletin No. 49. University of Alaska Sea Grant College Program, Fairbanks, AK, USA.

Bergkamp, L. 2001. Liability and environment: private and public law aspects of civil liability for environmental harm in an international context. Martinus Nijhoff Publishers, Leiden, The Netherlands.

Blumm, M. C., and R. D. Guthrie. 2012. Internationalizing the Public Trust Doctrine: Natural Law and Constitutional and 
Statutory Approaches to Fulfilling the Saxion Vision (April 20, 2011). University of California Davis Law Review, Vol. 44; Lewis \& Clark Law School Legal Studies Research Paper No. 2011-12. [online] URL: http://ssrn.com/abstract=1816628.

Bromley, D. W. 1990. The ideology of efficiency: searching for a theory of policy analysis. Journal of Environmental Economics and Management 19(1): 86-107. http://dx.doi. org/10.1016/0095-0696(90)90062-4

Bromley, D. W. 2005. Purging the frontier from our mind: crafting a new fisheries policy. Reviews in Fish Biology and Fisheries 15: 217-229. http://dx.doi.org/10.1007/s11160-005-4866$\underline{\mathrm{Z}}$

Bromley, D. W. 2008. The crisis in ocean governance: conceptual confusion, spurious economics, political indifference. MAST: Maritime Studies 6(2): 7-22.

Bromley, D. W. 2009. Abdicating responsibility: the deceits of fisheries policy. Fisheries Perspective: Socioeconomics 34 (6): 280-290. http://dx.doi.org/10.1577/1548-8446-34.6.280

Buchary, E. A., T. J. Pitcher, and U. R. Sumaila. 2011. Underaccounted values: under-reporting sardine catches as a strategy against poverty in the Bali Strait, Indonesia. Pages 203-223 in R. E. Ommer, R. I. Perry, K. Cochrane, and P. Cury, editors. World Fisheries: A Social-ecological Analysis. Fish and Aquatic Resources Series 14. Wiley-Blackwell, Oxford, UK.

Burns, R. 1785. To a Mouse, on Turning Her Up in Her Nest with the Plough, Kilmarnock Volume (Poems, Chiefly in the Scottish Dialect), published in 1786.

Buxton, N. 2011. The Law of Mother Earth: behind Bolivia's historic bill. A new law expected to pass in Bolivia mandates a fundamental ecological reorientation of the nation's economy and society. YES! Magazine. Retrieved from http:// www.yesmagazine.org/planet/the-law-of-mother-earth-behindbolivias-historic-bill.

Byrne, J. P. 2005. Property and environment: thoughts on an evolving relationship. Harvard Journal of Law and Public Policy 28: 679-689.

Camping, L. 2009. Fisheries subsidies: first WTO meeting to discuss Chair's 'roadmap' on fisheries subsidies disciplines. FFA Fisheries Trade News 2(2): 1-4.

Cheung, W. W. L., and T. J. Pitcher. 2008. Evaluating the status of exploited taxa in the northern South China Sea using intrinsic vulnerability and spatially explicit catch-per-uniteffort data. Fisheries Research 92: 28-40. http://dx.doi. org/10.1016/j.fishres.2007.12.018

Christy, F. T. 1997. The death rattle of open access and the advent of property rights regimes in fisheries. Marine Resource Economics 11: 287-304.
Chu, C. 2008. Thirty years later: the global growth of ITQs and their influence on stock status in marine fisheries. Fish and Fisheries 10: 217-230. http://dx.doi.org/10.1111/ j.1467-2979.2008.00313.x

Clean Air Act of 1963. (Public Law 88-206), United States Statutes at Large. 77 Statute 392.

Clean Air Act Extension of 1970 (Public Law 91-604), United States Statutes at Large. 84 Statute 1676. (codified in Title 42 (Public Health) United States Code $\$ 7401$ et seq. (1970)). [online] URL: http://epw.senate.gov/envlaws/cleanair.pdf.

Clean Water Act of 1972 or Federal Water Pollution Control Amendments of 1972 (Public Law 92-500), United States Statutes at Large. 86 Statute 816. (codified in Title 33 (Navigable Waters) United States Code $\$ 1251$ et seq. (1972)). [online] URL: http://epw.senate.gov/water.pdf.

Coase, R. H. 1960. The problem of social cost. The Journal of Law and Economics 3: 1-40. http://dx.doi.org/10.1086/466560

Communication from the Commission of the European Communities to the Council and Parliament and the Economic and Social Committee: Green Paper on Remedying Environmental Damage, COM 93 (47) final, Brussels, 14 May 1993.

Copes, P. 1986. A critical review of the individual quota as a device in fisheries management. Land Economics 62(3): 278291. http://dx.doi.org/10.2307/3146392

Costello, C., S. D. Gaines, and J. Lynham. 2008. Can catch shares prevent fisheries collapses? Science 321: 1678-1681. http://dx.doi.org/10.1126/science.1159478

Dayton, P. K. 1998. Ecology: Reversal of the burden of proof in fisheries management, Science 279: 821-822 http://dx.doi. org/10.1126/science.279.5352.821

Eagle, J. 2007. A window into the regulated commons: the Takings Clause, investment security, and sustainability. Ecology Law Quarterly 34: 619-654.

Eagle, J., and A. Kuker. 2010. Public fisheries. Ecology and Society 15(1): 10. [online] URL: http://www.ecologyandsociety. org/vol15/iss1/art10/.

Earth Charter. 2000. Available online: http://www. earthcharterinaction.org/content/pages/Read-the-Charter.html.

Epstein, R. A. 1995. The harm principle - and how it grew. University of Toronto Law Journal 45: 369-417. http://dx.doi. org/10.2307/825731

Farber, D. A. 2003. Building bridges over troubled waters: eco-pragmatism and the environmental prospect. Minnesota Law Review 87: 851-883. 
Fletcher, K. M. 2006. Regional ocean governance: the role of the Public Trust Doctrine. Duke Environmental Law and Policy Forum 16: 187-204.

Food and Agriculture Organization of the United Nations (FAO). 1995. Code of Conduct for responsible fisheries. FAO, Rome, Italy. [online] URL: ftp://ftp.fao.org/docrep/fao/005/ v9878e/v9878e00.pdf

Food and Agriculture Organization of the United Nations (FAO). 2001. International plan of action to prevent, deter and eliminate illegal, unreported and unregulated fishing. FAO, Rome, Italy. [online] URL: http://www.fao.org/ docrep/003/y1224e/y1224e00.HTM.

Garcia, S. M. 1994. The precautionary principle: its implications in capture fisheries management. Ocean and Coastal Management 22(2): 99-125. http://dx.doi. org/10.1016/0964-5691(94)90014-0

Grafton, R. Q. 1996. Individual transferable quotas: theory and practice. Reviews in Fish Biology and Fisheries 6: 5-20. http://dx.doi.org/10.1007/BF00058517

Grafton, R. Q., R. Arnason, T. Bjørndal, D. Campbell, H. F. Campbell, C. W. Clark, R. Connor, D. P. Dupont, R. Hannesson, R. Hilborn, J. E. Kirkley, T. Kompas, D. E. Lane, G. R. Munro, S. Pascoe, D. Squires, S. I. Steinshamn, B. R. Turris, and Q. Weninger. 2006. Perspective: incentive-based approaches to sustainable fisheries. Canadian Journal of Fisheries and Aquatic Sciences 63:699-710. http://dx.doi. org/10.1139/f05-247

Hannesson, R. 2004. The privatization of the oceans. MIT Press, Cambridge, MA.

Harris, D. C. 2008. The Boldt decision in Canada: Aboriginal treaty rights to fish on the Pacific. Pages 128-153 in A. Harmon, editor, The power of promises: rethinking Indian treaties in the Pacific Northwest. University of Washington Press, Seattle, WA. Available at SSRN: http://ssrn.com/ abstract $=1394436$.

Harris, D. C. 2009. Aboriginal rights to fish in British Columbia. Pages 496-506 in R. B. Anderson and R. M. Bone, editors. Natural resources and Aboriginal people in Canada: readings, cases, and commentary. Second edition. Captus Press, Concord, ON, Canada.

Hauck, M. 2008. Rethinking small-scale fisheries compliance. Marine Policy 32: 635-642. http://dx.doi.org/10.1016/j. marpol.2007.11.004

Heinberg, R. 2003. Fishing for trouble. The Ecologist 1st April 2003.

Hilborn, R. 2007. Managing fisheries is managing people: what has been learned? Fish and Fisheries 8: 285-296. http:// dx.doi.org/10.1111/j.1467-2979.2007.00263_2.x
Hilborn, R., J. K. Parrish, and K. Litle. 2005. Fishing rights or fishing wrongs? Reviews in Fish Biology and Fisheries 15: 191-199. http://dx.doi.org/10.1007/s11160-005-5138-7

International Convention for the Prevention of Pollution From Ships (MARPOL), adopted 2 November 1973, as modified by the Protocol of 1978 (MARPOL 73/78, with Annexes I and II, entered into force 2 October 1983), 1340 United Nations Treaty Series 61. Voluntary Annexes III - VI have been added and entered into force 1988 - 2005.

Johnsen, D. B. 2009. Salmon, science, and reciprocity on the Northwest Coast. Ecology and Society 14(2): 43. [online] URL: http://www.ecologyandsociety.org/vol14/iss2/art43/.

Jones, R., C. Rigg, and L. Lee. 2010. Haida marine planning: First Nations as a partner in marine conservation. Ecology and Society 15(1): 12. [online] URL: http:/www.ecologyandsociety. org/vol15/iss 1/art12/.

Juda, L. 1999. Considerations in developing a functional approach to the governance of large marine ecosystems. Ocean Development and International Law 30: 89-125. http://dx.doi. org/10.1080/009083299276203

Kaczynski, V. M., and D. L. Fluharty. 2002. European policies in West Africa: who benefits from fisheries agreements? Marine Policy 26: 75-93. http://dx.doi.org/10.1016/ S0308-597X(01)00039-2

Kahneman, D., and J. L. Knetsch. 1992. Valuing public goods: the purchase of moral satisfaction. Journal of Environmental Economics and Management 22: 57-70. http://dx.doi. org/10.1016/0095-0696(92)90019-S

Kipling, R. 1902. The wage-slaves. First published in The five nations 1903.

Lam, M. E., and T. Borch. 2011. Cultural valuing of fishery resources by the Norwegian Saami. Pages 361 - 376 in L. Westra, K. Bosselmann, C. Soskolne, editors, Globalisation and ecological integrity in science and international law. Cambridge Scholars Publishing, Cambridge, UK.

Lam, M. E., and M. E. Calcari Campbell, editors. 2012. The privilege to fish. Ecology and Society. Special Feature 37. [online] URL: http://www.ecologyandsociety.org/issues/ view.php/feature/37.

Lam, M. E., and D. Pauly. 2010. Who is right to fish? Evolving a social contract for ethical fisheries. Ecology and Society 15 (3): 16. [online] URL: http://www.ecologyandsociety.org/ vol15/iss3/art16/.

Lam, M. E., and T. J. Pitcher. 2012a. Fish commoditization: sustainability strategies to protect living fish. Bulletin of Science, Technology, and Society 32(1): 31-40. http://dx.doi. org/10.1177/0270467612444583 
Lam, M. E., and T. J. Pitcher. 2012b. The ethical dimensions of fisheries. Current Opinion in Environmental Sustainability 4: 364-373. http://dx.doi.org/10.1016/j.cosust.2012.06.008

Lauck, T., C. W. Clark, M. Mangel, and G. R. Munro. 1998. Implementing the precautionary principle in fisheries management through marine reserves. Ecological Applications 8(1): S72-S78.

Law of the Rights of Mother Earth (Spanish: Ley de Derechos de la Madre Tierra), Law 071 of the Bolivian Plurinational State. Available online (in Spanish): http://es.scribd.com/ doc/44900268/Ley-de-Derechos-de-la-Madre-Tierra-EstadoPlurinacional-de-Bolivia.

Lazarus, R. J. 1986. Changing conceptions of property and sovereignty in natural resources: questioning the public trust doctrine. Iowa Law Review 71: 631-716.

Leopold, A. 1949. A Sand County almanac: with essays on conservation from Round River. Ballantine Books, New York, NY.

Lin, A. C. 2006. The unifying role of harm in environmental law. Wisconsin Law Review 897-985.

Macdonald, J. M. 1995. Appreciating the precautionary principle as an ethical evolution in ocean management. Ocean Development \& International Law 26: 255-286. http://dx.doi. org/10.1080/00908329509546062

McClenachan, L. 2009a. Documenting loss of large trophy fish from the Florida Keys with historical photographs. Conservation Biology 23(3): 636-643. $\underline{\text { http://dx.doi. }}$ org/10.1111/j.1523-1739.2008.01152.x

McClenachan, L. 2009b. Historical declines in south Florida, USA goliath grouper populations. Endangered Species Research. 7: 175-181. http://dx.doi.org/10.3354/esr00167

Macinko, S., and D. W. Bromley. 2002. Who owns America's fisheries? Island Press. Washington, D.C. USA.

Macinko, S, and D. W. Bromley. 2004. Property and fisheries for the twenty-first century: seeking coherence from legal and economic doctrine. Vermont Law Review 28: 623-661.

Mangel, M., L. M. Talbot, G. K. Meffe, M. T. Agardy, D. L. Alverson, J. Barlow, D. B. Botkin, G. Budowski, T. Clark, J. Cooke, R. H. Crozier, P. K. Dayton, D. L. Elder, C. W. Fowler, S. Funtowicz, J. Giske, D. Ludwig, K. Magnusson, B. S. Malayang III, C. Mann, E. A. Norse, S. P. Northridge, W. F. Perrin, C. Perrings, R. M. Peterman, G. B. Rabb, H. A. Regier, J. E. Reynolds III, K. Sherman, M. P. Sissenwine, T. D. Smith, A. Starfield, R. J. Taylor, M. F. Tillman, C. Toft, J. R. Twiss, Jr., J. Wilen, and T. P. Young. 1996. Principles for the conservation of wild living resources. Ecological Applications 6(2): 338-362. http://dx.doi.org/10.2307/2269369
Montreal Protocol on Substances that Deplete the Ozone Layer (a protocol to the Vienna Convention for the Protection of the Ozone Layer 1985), adopted 16 September 1987 and effective 1 January 1989), Treaties and Other International Acts Series No. 11,097; 1513 United Nations Treaty Series 323. [online] URL:: http://ozone.unep.org/Ratification_status/montreal_protocol. shtml.

Nagle, J. C. 2001. Moral nuisances. Emory Law Journal 50: 265-322.

Neher, P. A., R. Arnason, and N. Mollett, editors. 1989. Rights based fishing: proceedings of a workshop on the scientific foundations for rights based fishing. Kluwer Academic Publishers, Dordrecht, the Netherlands.

Pardy, B. 2005. In search of the holy grail of environmental law: a rule to solve the problem. McGill International Journal of Sustainable Development Law and Policy 1(1): 29-57.

Pauly, D. 1995. Anecdotes and the shifting baseline syndrome of fisheries. Trends in Ecology and Evolution 10(10): 430. http://dx.doi.org/10.1016/S0169-5347(00)89171-5

Pauly, D. 2006. Major trends in small-scale marine fisheries, with emphasis on developing countries, and some implications for the social sciences. MAST:Maritime Studies 4(2): 7-22.

Pauly, D., and J. Maclean. 2003. In a perfect ocean: the state offisheries and ecosystems in the North Atlantic Ocean. Island Press, Washington, DC, USA.

Pearse, P. H., and C. J. Walters. 1992. Harvesting regulation under quota management systems for ocean fisheries. Marine Policy May 1992 167-182. http://dx.doi.org/10.1016/0308-597X (92)90079-5

Pedersen, W. F. 1994. "Protecting the environment" - what does that mean? Loyola of Los Angeles Law Review 27: 969-979.

Peltzman, S. 1976. Toward a more general theory of regulation. Journal of Law and Economics 19(2): 211-240. http://dx.doi.org/10.1086/466865

Peltzman, S. 1993. George Stigler's contribution to the economic analysis of regulation. The Journal of Political Economy 101: 818-832. http://dx.doi.org/10.1086/261904

Pigou, A. C. 1932. The economics of welfare. Macmillan and Co. London, UK. Fourth Edition.

Pitcher, T. J., D. Kalikoski, K. Short, D. Varkey, and G. Pramod. 2008. An evaluation of progress in implementing ecosystem-based management of fisheries in 33 countries. Marine Policy 33: 223- 232. http://dx.doi.org/10.1016/j. marpol.2008.06.002

Pitcher, T. J., D. Kalikoski, G. Pramod, and K. Short. $2009 a$. Safe conduct? Twelve years fishing under the UN Code. World Wildlife Fund, Gland, Switzerland. 
Pitcher, T. J., and M. E. Lam. 2010. Fishful thinking: rhetoric, reality, and the sea before us. Ecology and Society 15(2): 12. [online] URL: http://www.ecologyandsociety.org/vol15/iss2/ art12/.

Pitcher, T. J., G. Pramod, D. Kalikoski, and K. Short. $2009 b$. Commentary: Not honouring the code. Nature 457: 658-659.

Poostchi, B. 1996. Follow-up to the 1993 green paper on environmental liability. Review of European Community and International Environmental Law 5(4): 328-334. http://dx.doi. org/10.1111/j.1467-9388.1996.tb00297.x

Pope, T. M. 2000. Balancing public health against individual liberty: the ethics of smoking regulations. University of Pittsburgh Law Review 61: 419-498.

Power-Antweiler, M. D., and T. J. Pitcher. 2008. Reconciling fisheries and allocation using a justice-based approach: troll fisheries score best. Pages 63-78 in J. L. Nielsen, J. J. Dodson, K. Friedland, T. R. Hamon, J. Musick, and E. Verspoor, editors. Reconciling Fisheries with Conservation: Proceedings of the Fourth World Fisheries Congress. American Fisheries Society, Symposium 49, Bethesda, MA, USA.

Pramod, G. and T. J. Pitcher. 2006. An Estimation of Compliance of the Fisheries of Ireland with Article 7 (Fisheries Management) of the FAO (UN) Code of Conduct for Responsible Fishing. Page 36 (with 23 linked pages) in T. J. Pitcher, D. Kalikoski, and G. Pramod, editors. Evaluations of Compliance with the FAO (UN) Code of Conduct for Responsible Fisheries. Fisheries Centre Research Reports 14 (2): 1192pp. The Fisheries Centre, University of British Columbia, Vancouver, BC, Canada.

Raymond, L. 1996. The ethics of compensation: takings, utility, and justice. Ecology Law Quarterly 23: 577-622.

Rio Declaration on Environment and Development (Rio Declaration, produced at the 1992 United Nations "Conference on Environment and Development" (UNCED) or Earth Summit).

Rosenberg, A. A. 2009. Changing U.S. ocean policy can set a new direction for marine resource management. Ecology and Society 14(2): 6. [online] URL: http://www.ecologyandsociety. org/vol14/iss2/art6/.

Ruhl, J. B. 2000. Working both (positivist) ends toward a new (pragmatist) middle in environmental law. George Washington Law Review 68(3): 522-546. http://dx.doi. org/10.2139/ssrn.214528

Ruhl, J. B. 2007. The "background principles" of natural capital and ecosystem services - Did Lucas open Pandora's box? Journal of Land Use 22(2): 525-547.

Ruhl, J. B. 2008. Making nuisance ecological. Case Western Law Review 58(3): 753-785.
Ruhl, J. B., and J. Salzman. 2006. Ecosystem services and the Public Trust Doctrine: working change from within. Southeastern Environmental Law Journal 15(1): 223-239.

Safina, C. 1997. Song for the blue ocean: encounters along the world's coasts and beneath the sea. Henry Holt and Company, New York, NY, USA.

Safina, C. 2003. Launching a sea ethic. Wild Earth 12(4): 2-5.

Sand, P. H. 2007. Public trusteeship for the oceans. Pages 521-544 in T. M. Ndiaye and R. Wolfrum, editors. Law of the sea, environmental law and settlement of disputes: Liber Amicorum Judge Thomas A. Mensah. Koninklijke Brill NV, Leiden, Netherlands.

Sax, J. L. 1970. The Public Trust Doctrine in natural resource law: effective judicial intervention. Michigan Law Review 471-566. http://dx.doi.org/10.2307/1287556

Sax, J. L. 1993. Property rights and the economy of nature: understanding Lucas v. South Carolina Coastal Council. Stanford Law Review 45: 1433-1455. http://dx.doi. org/10.2307/1229075

Schroeder, C. H. 2002. Lost in translation: what environmental regulation does that tort cannot duplicate. Washburn Law Journal 41: 583-606.

Shane, P. M. 1991. Structure, relationship, ideology, or, how would we know a "new public law" if we saw it? Michigan Law Review 89: 837-874. http://dx.doi.org/10.2307/1289522

Sissenwine, M. P., and P. M. Mace. 2003. Governance for responsible fisheries: an ecosystem approach. Pages 363-391 in M. Sinclair and G. Valdimarsson, editors. Responsible fisheries in the marine ecosystem. Food and Agriculture Organization of the United Nations, Rome, Italy.

Spence, D. B. 2001. The shadow of the rational polluter: rethinking the role of rational actor models in environmental law. California Law Review 89: 917-998. http://dx.doi. org/10.2307/3481289

Stefansson, G., and A. A. Rosenberg. 2005. Combining control measures for more effective management of fisheries under uncertainty: quotas, effort limitation and protected areas. Philosophical Transactions of the Royal Society B 360: 133-146. http://dx.doi.org/10.1098/rstb.2004.1579

Steinbeck, J. 1937. Of Mice and Men. Penguin Books. Harmondsworth, Middlesex, England.

Stigler, G. J. 1971. The theory of economic regulation. Bell Journal of Economics and Management Science 2: 3-21. http://dx.doi.org/10.2307/3003160

Stone, C. D. 1972. Should trees have standing? - Toward legal rights for natural objects. Southern California Law Review 45: 450-501. 
Sumaila, U. R. 2010. A cautionary note on individual transferable quotas. Ecology and Society 15(3): 36. [online] URL: http://www.ecologyandsociety.org/vol15/iss3/art36/.

Sumaila, U. R., and D. Pauly. 2007. All fishing nations must unite to cut subsidies. Nature 450: 945. http://dx.doi. org/10.1038/450945a

Taylor, P. 2011. Common heritage of mankind principle. Pages 64-69 in K. Bosselmann, D. Fogel, and J. B. Ruhl, editors, The encyclopedia of sustainability, vol. 3: the law and politics of sustainability. Berkshire Publishing, Great Barrington, MA, USA.

Trites, A. W., V. Christensen, and D. Pauly. 1997. Competition between fisheries and marine mammals for prey and primary production in the Pacific Ocean. Journal of North West Atlantic Fishery Science 22: 173-187. http://dx.doi.org/10.2960/J.v22. a14

Trosper, R. L. 2002. Northwest coast indigenous institutions that supported resilience and sustainability. Ecological Economics 41: 329-344. http://dx.doi.org/10.1016/S0921-8009 (02)00041-1

Trosper, R. L. 2003. Resilience in pre-contact Pacific Northwest social ecological systems. Conservation Ecology 7 (3): 6. [online] URL: http://www.ecologyandsociety.org/ vol7/iss $3 /$ art6/.

Turner, G. F. 1995. Management, conservation and species changes of exploited fish stocks in Lake Malawi. Pages 335-395 in T. J. Pitcher and P. J. B. Hart, editors. The impact of species changes in African Lakes. Chapman and Hall, London, UK.

Turnipseed, M., L. B. Crowder, R. D. Sagarin, and S. E. Roady. 2009a. Legal bedrock for rebuilding America's ocean ecosystems. Science 324: 183-184. http://dx.doi.org/10.1126/ science. 1170889

Turnipseed, M., S. E. Roady, R. Sagarin, and L. B. Crowder. $2009 \mathrm{~b}$. The silver anniversary of the United States' Exclusive Economic Zone: twenty-five years of ocean use and abuse, and the possibility of a blue water Public Trust Doctrine. Ecology Law Review 36: 1-70.

United Nations Agreement for the Implementation of the Provisions of the United Nations Convention on the Law of the Sea of 10 December 1982 Relating to the Conservation and Management of Straddling Fish Stocks and Highly Migratory Fish Stocks (adopted 4 August 1995, opened for signature 4 December 1995, and entered into force 11 December 2001).

United Nations Convention on the Law of the Sea (UNCLOS III, concluded 10 December 1982, entered into force 16 November 1994), 1833 United Nations Treaty Series 397, United Nations Document A/Conf.61/122. Available online:
http://www.un.org/Depts/los/convention agreements/texts/unclos/ unclos e.pdf

Universal Declaration of Human Rights (UDHR) 1948 (adopted 10 December 1948 by the United Nations General Assembly Resolution 217A (III), United Nations Document $\mathrm{A} / 810$ at 71). Available online: http://www.un.org/en/ documents/udhr/index.shtml.

Watson, R. A., W. W. L. Cheung, J. A. Anticamara, R. U. Sumaila, D. Zeller, and D. Pauly, Global marine yield halved as fishing intensity redoubles, Fish and Fisheries http://dx. doi.org/10.1111/j.1467-2979.2012.00483.x.

Wilgus, D. S. 2001. The nature of nuisance: judicial environmental ethics and landowner stewardship in the age of ecology. McGeorge Law Review 33:99-128.

Williamson, O. E. 1979. Transaction-cost economics: the governance of contractual relations. The Journal of Law and Economics 22: 233-261. http://dx.doi.org/10.1086/466942

Wilson, J. 2007. Scale and costs of fishery conservation. International Journal of the Commons 1: 29-41.

World Trade Organization (WTO). 2011. Communications from the Chairman of the Trade Negotiations Committee on Rules: antidumping, subsidies, fisheries subsidies. http:// www.wto.org/english/tratop_e/dda e/chair texts11 e/chair texts11_e. $\underline{\mathrm{htm}}$.

Wyman, K. M. 2008. The property rights challenge in marine fisheries. Arizona Law Review 50: 511-543. 